\title{
Blood accusation and Orthodox liturgy in the Russian Empire before and after the Beilis Case
}

\author{
N. Kizenko \\ State University of New York at Albany, \\ 1400, Washington Ave, Albany, New York, 12222, USA
}

For citation: Kitsenko N. Blood accusation and Orthodox liturgy in the Russian Empire before and after the Beilis Case. Vestnik of Saint Petersburg University. Philosophy and Conflict Studies, 2020, vol.36, issue 1, pp. 179-195. https://doi.org/10.21638/spbu17.2020.115

Although Gavriil died in 1690, he became the object of cult veneration in late imperial Russia at the end of the $19^{\text {th }}$ century. This period, the golden age of what Eric Hobsbawm called "the invention of tradition", was also a time of rising anti-Semitism and blood accusation in the Russian empire. The 1908 service (Small Vespers, Great Vespers, Matins) composed in Gavriil's honor contains numerous quotations and reworkings of the anti-Jewish texts from Byzantine Passion Week, Great Friday in particular. The imagery from Byzantine liturgy provided a familiar and resonant template that allowed it to spark associations in the Russian empire between the revolutions of 1905 and 1917. The Gavriil service prompts the question of whether liturgical texts can be held responsible for Christian religious antisemitism. It provides context for anxieties focusing on the Jews in late imperial Russia and as a possible background for the 1911-1913 Beilis blood accusation case. Most historians argue that by the early $20^{\text {th }}$ century, the theological underpinnings of antisemitism were replaced by a backlash against the ideologies of liberalism and Marxism, and-in the Russian empire-the greater integration of Jews into society as a result of the Great Reforms of Alexander II. The service to Gavriil and the persistent tensions during Holy Week, however, shows the enduring importance of the religious context in ritual murder trials and accusations, particularly in the Pale of Settlement (present-day Belarus and Ukraine). The veneration of Gavriil in the Soviet and post-Soviet periods in Poland, Belarus, and beyond, reflects different tensions.

Keywords: blood accusation, ritual murder, Gavriil of Bialystok, Beilis, Ioannikii (Haliatovskii), Antonii (Khrapovitskii) Slutsk, Zabludowa, canonization, saints.

One of the first things the attorneys sought in the Beilis case of 1911-1913, in which Mendel Beilis was tried for the ostensible ritual murder of thirteen-year-old Andrei Iushchinskii, was an Orthodox Christian cleric who could serve as an expert witness. However, they ran into an unexpected difficulty. No such person could be found. In an empire covering one-sixth of the earth's surface with four Orthodox theological academies and over a hundred Orthodox seminaries, there was no shortage of educated churchmen. And yet not a single one had anything to say about it.

The defense attorney in the Beilis case, O.O.Gruzenberg, turned this into an unexpected compliment. It was to the credit of Orthodoxy, he claimed, that not a single Orthodox cleric could be found to testify on the previous history of ritual murder: the only expert witness in the case was a Polish Catholic priest [1]. This ostensible absence is the subject of this paper.

(C) Санкт-Петербургский государственный университет, 2020 
The charge of ritual murder, also known as 'blood accusation,' has a long history. Nearly every European country, from England to Poland to Germany, has its own Christian 'martyrs', usually children, in this category. William of Norwich, who was killed in 1144 , is only the first example [2, p. 515-536; 3-5]. At first glance, Russia is strangely absent. If one looks up the subject heading 'blood accusation' in the Library of Congress, until the nineteenth century there are almost no such headings for Russia; most come from Poland, Germany, Bohemia, or England [6]. If one treats the blood accusation as a litmus test of anti-Semitism, then Russian Orthodoxy appears to be an anomaly. Indeed, Laura Engelstein has argued that Russian anti-Semitism was not a local product, but something imported from Europe along with the other attributes of modernity [7].

If there appears to be no indigenous Russian tradition of the blood accusation, where did the Beilis case come from? The reason for this, of course, lies in the shape-shifting of the Russian empire. Until the partitions of Poland at the end of the $18^{\text {th }}$ century, there were almost no Jews in Russia proper. Thus there was literally no possibility for the blood accusation to arise. Although the Orthodox Christian liturgical texts of Passion Week are not shy about assigning blame to Caiphas and the Sanhendrin, in the absence of concrete Jews around the corner who might realistically be blamed, popular imagination did not extend as far as the blood accusation. On the other hand, the general idea that symbolic blood and bread, meant to be used for ritual purposes, could be inverted and used for other means did exist: priests could blame and did blame their Orthodox Christian parishioners, and Old Believers, too, for using the Eucharist for magical rituals, albeit mostly as a love potion [8;9]. Eugene Avrutin, one of the leading scholars of the ritual murder accusation in the Russian empire, notes that "in the Russian empire, the production and consumption of accusatory literature on the blood libel lacked the vigor of those works produced in early modern Poland" [10, p. 139].

Orthodox Christians who lived in the territory of the Polish-Lithuanian Commonwealth with the largest Jewish population in Europe-that is, Ukrainians and Belarusians-were a different story. Here we do find two Orthodox phenomena, both from the late seventeenth century, that might lead us to the Beilis case. The first East Slavic Orthodox theologian to articulate the blood accusation was Archimandrite Ioanikii Haliatovskii. His 'Righteous Messiah' («Мессия правдивый»), was first published in Polish in Chernihiv, and in Ukrainian translation in Kiev in 1669 [11]. In describing various Jewish "evil deeds," Haliatovskii included twelve examples of ritual murder in different European countries (taken mostly from Polish and Jewish sources), and adduced four reasons for why Jews might need the blood of Christian children:

- magic,

- to slip into the food and drink of Christians to gain their goodwill,

- to free themselves from "stench",

- something known supposedly only to rabbis: in a variant of unction, that dying Jews were anointed with Christian blood with a ritual incantation to the effect that if the crucified Jesus were indeed the real Messiah, this blood would cleanse the dying Jew of that guilt and serve to gain eternal life [12].

This curious projection of what Ruthenian Christians imagined about their Jewish neighbors says far more about their own fears and fantasies. Haliatovskii's book was known among clerics at the end of the seventeenth century, but it seems to have affected 
Old Believers, who were accused of similar atrocities, more immediately than it did Jews. Moreover, while it may have helped to form early blood accusation perceptions among Russian clerics, it is hard to link it to later blood accusation cases in the Russian empire.

Another source is more promising. Not long after Haliatovskii's book, the Eastern Slavic Orthodox tradition acquired a martyr from the blood accusation category St. Gavriil of Bialystok, an Orthodox Christian boy killed at the age of six in 1690. His veneration took centuries to develop, and he was canonized locally and only in 1914. What happened in the two hundred years after Gavriil's death, what explains the far later date of his liturgical veneration-so close in timing to the Beilis case-and what happened to his cult after the Beilis acquittal, is the subject of this article.

Gavriil's veneration is a valuable case study of what Eric Hobsbawm called "the invention of tradition." His cult arose at a time of rising anti-Semitism and blood accusation in the Russian empire. The 1908 service (Small Vespers, Great Vespers, Matins) composed in Gavriil's honor contains numerous quotations and reworkings of the anti-Jewish texts from Passion Week, Great Friday in particular [13]. The imagery from Byzantine liturgy provided a familiar and resonant template that allowed it to spark associations in the very different context of the Russian empire between the revolutions of 1905 and 1917. In a broader Orthodox context, the Gavriil service prompts a question dealt with earlier by the Roman Catholic Church, of whether liturgical texts can be held responsible for Christian religious anti-Semitism $[14 ; 15]$. It also provides background for anxieties focusing on the Jews in late imperial Russia and for the Beilis blood accusation case. Many historians argue that by the turn of the $20^{\text {th }}$ century, the theological underpinnings of antisemitism were replaced by a backlash against the ideologies of liberalism and Marxism, and the greater integration of Jews into society as a result of the Great Reforms of Alexander II [6, p.7]. While this may be true from the point of view of reception, the service to Gavriil and persistent Christian-Jewish tensions during Holy Week show the enduring importance of the religious context in ritual murder trials and accusations.

There is little surviving evidence for any cult or veneration of Gavriil in the first century after his death in 1690. In itself, this is not surprising. Both the Russian Orthodox and Roman Catholic Churches emphasized enlightenment and decried 'superstition' throughout much of the eighteenth century [16]. There was also the simple fact that Gavriil lived and died in a borderland area that is now Poland. In the eighteenth century in the Polish-Lithuanian Commonwealth and the Habsburg Empire, there was no constituency for him except for the often-beleaguered Orthodox clergy [17].

This would change, however, after the late $18^{\text {th }}$ century partitions of Poland and the incorporation of the 'Pale of Settlement' into the Russian empire. The first mention of 'the martyr Gavriil' in print, a church history published in Russian in 1815, cited records from the Trinity Monastery of Slutsk. According to that brief account, Gavriil was born in 1684 in the village of Zwierki near Zabludowa. In 1690, Gavriil was kidnapped by a Jewish lessee (arendator), tortured to death, his body then thrown in the fields to be carrion for birds of prey. His parents found his body, had it 'testified' (по освидетельствовали погребли) and buried it in the Zabludowa monastery. When in 1746 in the course of another burial the body was found to be whole and incorrupt, starting local popular veneration, it was transferred to the monastery crypt. On May 9, 1755, the archimandrite of the Trinity monastery of Slutsk, Mikhail Kazachinskii, had the body transferred to his own monastery [18, p. 149]. In sum, when Gavriil first appeared in the Russian language, he was briefly 
acknowledged as being the object of a local cult in the Russian empire-far from the allimperial veneration accorded to such luminaries as Bishop Dimitri of Rostov (canonized 1757) or Bishop Mitrofan of Voronezh (canonized 1832). Gavriil made it into this source, which dealt primarily with church monuments and architecture, only insofar as he was one of many minor, equally remarkable, aspects of the Trinity Monastery of Slutsk.

Two compilations of Russian saints' lives from 1862 and 1865, however, already refer to Gavriil's body as 'relics,' and include both a kontakion and a verse account of his martyrdom in Polish [19, p.60; 20, p. 517-519]. In itself, this is not surprising. In hagiography, later versions of a story often embellish upon an initial laconic mention. Gavriil's vita thus follows familiar practice, but the label of 'saint' is more ambiguous than it might seem. The word glorified does not refer to a formal canonization: despite later, unsubstantiated accounts claiming an 1820 canonization (the Orthodox Encyclopedia and other sources repeat this mistake), Gavriil appears in no list of Russian saints canonized in the notoriously canonization-unfriendly Synodal period from 1721 to 1894 [21;22]. This is partly a function of historical circumstance. Precisely because of the structural difficulties with formal, empire-wide canonization, the late nineteenth century saw a host of attempts to compile accounts of local holy people (подвижники благочестия) as potential preparation for better times. The Life Accounts of Native Strugglers of Piety (Zhizneopisaniia otechestvennykh podvizhnikov blagochestiia) is the only best-known example [23]. Gavriil's inclusion in compilations of Russian saints, 'whether venerated locally or Church-wide,' needs to be seen in this climate of local ethnographic, geographic, and hagiographic enthusiasm [24]. Moreover, the $19^{\text {th }}$ century was the golden age of what Eric Hobsbawm calls the invention of tradition: in Russia, as in western Europe and Japan, religious institutions were inventing or elaborating pedigrees for both people and places, like the Valaam monastery [25]. The reigns of Alexander III and Nicholas II were the high point of the national myth in politics and the Russian style in church architecture [26]. But the presence of a kontakion hymn by the mid- $19^{\text {th }}$ century is something tangible and serious: it suggests that at some point between 1755 and 1865 some formal, liturgical commemoration of Gavriil had already formed and was already in place. The existence of this hymn, and its publication, means that the monastery with his relics had taken the trouble to create something specific, as opposed to something generic, that might be sung on the day of his commemoration. Gavriil had thus reached the first, minimum, baseline marker of being included in liturgy. Not yet a full service-far from it-but enough to indicate that a saint was considered important enough to have some specifics mentioned in a dedicated liturgical hymn.

Texts, of course, are not the only indicator of veneration. Before the twentieth century, visual depictions of holy figures often appeared before texts, followed by church dedications [27]. The Pochaev Lavra contains a fresco of Gavriil which appears to date from the $19^{\text {th }}$ century. Other details also suggest that the cult of Gavriil took on momentum at the end of the nineteenth century. In 1893, Archbishop Donat Babinskii-Sokolov ordered that all the churches in his diocese have icons with a depiction of the martyr. In 1897, believers donated money for a silver case to house Gavriil's relics. The relics were open, so that the wounds on his pierced hands were visible. The Slutsk monastery started to keep a record of miracles occurring in front of that reliquary, and the Grodno diocesan news reported them, describing Gavriil as a 'saint' and 'martyr.' The introduction of an annual procession from the chapel built on the location of Gabriel's birthplace to the Slutsk monastery, also 
meant the broader dissemination of small mass-produced icons of Gabriel in Zabludowa parishes [28, p. 200-203].

This veneration did not happen in a void. Translations into Russian from other languages of the blood accusation started to appear for the first time in the middle of the $19^{\text {th }}$ century - and rebuttals as well [29-32]. Blood accusation cases began in the nineteenth century ${ }^{1}$. (Even the celebrated scholar Vladimir Dal' was reputed to have devoted a volume to the subject [33], although its authenticity has been called into question [34;35]). The Great Reforms of Alexander II had made it possible for many more Jews to move outside the Pale of Settlement and to occupy a more prominent role in society. This meant more opportunities-but also more tensions, resulting in such events as the Kishinev pogrom of 1903. The Revolution of 1905 brought even more opportunities - and tensions and violence - to the surface [36].

It is thus not surprising in this climate that one of the leading hierarchs in Volyn, Archbishop Antonii Khrapovitskii, was interviewed in 1905 by a small newspaper in Zhitomir about ritual murder ${ }^{2}$. Perhaps more surprising was his response. He said that, given the punishment meted out to Saul and his descendants in the book of Kings, some contemporary variant of ritual murder might exist. He added that if it existed, it should not be regarded as a disgusting relic of the past, but a political tactic for maintaining the nation's purity. Finally, and perhaps most sensationally, he added that whether or not ritual murder existed, that was not what Christians ought to be worrying about: the loss of one youth or infant out of the 200 million population of Russia, bad though that would be, would still be less bad than the general demoralization the Jews were spreading in Christian society. And this was one of the most eminent hierarchs who after the Kishinev pogrom had argued ardently in defense of the Jewish community and who had held up contemporary observant Jews as an example to be emulated by Orthodox Christians [39]. Perhaps partly as a reflection of these sentiments, Antonii penned a full service to Gavriil soon after, submitting it to the Synod on November 23, $1905[40-42]^{3}$.

Veneration of Gavriil grew by leaps and bounds. Monks from the Slutsk monastery began to keep records of miracles at his bier. By the beginning of the $20^{\text {th }}$ century, the day of his martyrdom, April 20, marked a major annual pilgrimage, attracting as many as 35,000 people. Part of Gavriil's relics were brought to Moscow and displayed in a case in the Protection Cathedral, more commonly known as St. Basil's. In 1908-1909, the liturgical service for him was finally approved for publication by the Holy Synod [43]. In its choice of languages, images, and metaphors, it provides an invaluable context for anxieties focusing on the Jews in late imperial Russia and for the Beilis case.

\footnotetext{
${ }^{1}$ Major blood accusation cases in the Russian empire before the Beilis case included those in Velizh (1823), Saratov (1852-1860, involving a particularly large number of people), and Kutaisi (1879) (see [31]).

${ }^{2}$ For a detailed examination of the role of both Metropolitan Antonii Khrapovitskii and the Pochaev Lavra in the Union of the Russian People, see [37, S. 213-240; 38].

${ }^{3}$ Although Antonii is nowhere listed as the writer on the text, on the occasion of Gavriil's local canonization, he was publicly praised for its writing by Mitrofan, Bishop of Minsk and Turov [40], and Priest A. Khvalebnov [41]. According to an unpublished dissertation by Hieromonk German (Veinberg), Antonii submitted the service to the Synod in November 1905 and followed up with an explanatory note five months later, explaining that he had used the existing troparion and kontakion and composed the rest of the service on the basis of the Life (personal communication from Aleksandr Kravetsky, June 2019).
} 


\section{"The Service to the Holy Martyr Infant Gavriil, Martyred in the Year of Our Lord 1690 in the City of Bialystok"}

As Gavriil was killed on the eve of Easter 1690 - which that year fell on April 20 the date of his veneration coincided with the Paschal period and Passover, typically a period of tension among Christians and Jews in the Polish-Lithuanian Commonwealth (and, after the partitions of Poland, in the Russian empire) [44; 45]. The service drew on and fostered those tensions. In many places the text directly evokes and paraphrases parts of the Holy Thursday and Friday services of Passion Week. Its overall message is that Gavriil is a latter-day Christ figure 'again' martyred by Jews. His age is crucial: he was not yet seven when he died, and thus 'innocent'. This innocence and lack of guile are held up as an example to contemporary Russians who might be tempted by the wiliness of the "Jews and those like them".

The first sticheron of the Gavriil service sets the stage. As Christ was preparing to drink from the cup of His passion, it says, He told his disciples that if they were not as innocent as children, they could not enter the kingdom of heaven ("Аще не обратитеся и не яко младенцы незлобивіи пребудете, не можете въ царствіе небесное внити: сице научает други своя Христосъ, имже чашу страстей своихъ овъщавает пити”). Gabriel did take up this salvific cup through his martyrdom, and thus earned boldness to pray for the salvation of other Christians in the Russian empire. The stichera following explicitly parallel and paraphrase those from Passion Week.

Service to Gavriil: "Стекается соборище иудейское/от Бреста же и ББлостока,/да непорочнаго младенца мукамъ предаетъ: / о безаконныхъ, о неверныхъ!..” [43, p. 2]

The assembly of the Jews gathers together from Brest to Bialystok to deliver to torment the immaculate infant. What lawlessness! What faithlessness! ${ }^{4}$

Compare to Great and Holy Thursday: "Стекается прочее соборище иудейское, / да содътеля и зиждителя всяческихъ Пшату предастъ: / о безаконныхъ, о невърныхъ!..” [46, p. 442].

The assembly of the Jews gathers together to deliver to Pilate the Maker and Creator of all. What lawlessness! What faithlessness!

Service to Gavriil: "Ужас бе видъти/родителем младенческое тело лють истерзанно на нивъ посреде псов аки стражей върных лежащее/из негоже всю кровь мучители извлекоша / и кожу его повсюду прободоша...” [43, p. 6].

A strange horror it was for parents to see their infant's body mutilated in the field among hounds lying like faithful guards, from which the tormenters drew out all his blood and pierced his skin...the sun was darkened and the day was changed unto night.

Compare to Great and Holy Friday: "Ужасъ бе видъти/небесе и земли творца на крест висяща,/ солнце померкшее, / день же паки въ нощь преложшшся...”

A strange horror it was to see the maker of Heaven and earth suspended on the cross...the sun was darkened and day was changed into night [46, p. 446].

After the $50^{\text {th }}$ Psalm, a lengthy stikhira paraphrases two key Holy Friday texts, "Today Judas leaves the Teacher" and "Today Hangs Upon the Wood" “"Днесь Иуда оставляетъ Учителя и пріемлетъ діавола” and “Днесь виситъ на древб”).

Service to Gavriil: “Днесь льстивными словеса младенецъ из дома отча изводится, днесь неповинная того кровь проливается и въ подземная святый

\footnotetext{
${ }^{4}$ Unless otherwise noted, all translations are the author's.
} 
Гавріилъ отъ іудей заключается, и мучителей сонмище собирается, днесь совЂтъ злобы исполняется и лютой смерти отроча предается..."

Today a child is lured from his father's home with lying words, today his innocent blood is shed. The holy Gabriel is covered with earth by the Jews, and the assembly of tormenters gather together. Today the council of malice is fulfilled, and the child is given over to a cruel death... [47, p. 102]

Compare to its models in Great and Holy Friday Matins:

Днесь Иуда оставляет Учителя и приемлет диавола, ослепляется страстию сребролюбия, отпадает Света омраченный: како бо можаше зрети, Светило продавый на тридесятих сребреницех? Но нам возсия Страдавый за мир..

Днесь Иуда притворяет благочестие и отчуждается дарования, сый ученик бывает предатель: во обычном лобзании лесть покрывает, и предпочитает Владычния любве, несмысленно работати сребролюбию, наставник быв соборища беззаконнаго...

Днесь висит на древе, Иже на водах землю повесивый; венцем от терния облагается, Иже Ангелов Царь; в ложную багряницу облачается, одеваяй небо облаки; заушение прият, Иже во Иордане свободивый Адама гвоздьми пригвоздися Жених Церковный; копием прободеся Сын Девы... [46, p. 443, 446, 452, 474, 474ob.]

These are only three examples: the entire service is full of such analogies and direct paraphrases. The explicit parallels between Gabriel's service and those from Holy Friday, often using the same tone as the prototype, would have heightened the effect for those present: Gavriil's martyrdom was a latter-day version of the Passion of Christ. By drawing on the existing rich imagery of Passion Week, the service to Gavriil emphasizes the theme of the nefarious Jews plotting against an innocent Christian and seeks to apply it to the 'present,' whether the $17^{\text {th }}$ century or the twentieth. The last sticheron at the end of the Praises makes the connection clear: "While Christians were celebrating the week of the Passion of Christ, and preparing their souls to greet Holy Pascha, the child Gabriel was subjected to suffering by the Jews, and, crucified on the wall of a dark cellar for the crucified Savior, he shed his blood as the day of the Lord's resurrection arrived. His spirit departed unto Christ in the mansions of Heaven, but the Jews cast his body out beyond the village. Yet, remaining incorrupt even to this day, it proclaimeth the general resurrection..." [47, p. 106].

Imperial-era Russian Orthodox hymnography had rarely gone so far. In one respect, however, Archbishop Antonii's Gavriil service showed some liturgical tact. Despite its explicit parallels to Passion Week, it was not meant to be celebrated on Passion Week itself. The rubrics for the service specified that, if in any given year April 20 happened to coincide with any of the first four days of Passion Week, Gavriil's service was to be moved to Palm Sunday (which conveniently had plenty of its own references to "the children of Israel" first shouting 'Hosanna' and then 'crucify Him'). If it fell on the last days of Holy Week or Easter itself, it was to be moved to Bright Monday, unless that was St. George's Day, in which case to Bright Tuesday [48]. So, while the service exploited Passion Week imagery, it did not actually intrude upon Passion Week itself, nor on the celebration of a universally revered saint. 
This ultimate separation of Gabriel from Passion Week suggests that the service was perhaps meant less to serve a liturgical function than a political one. And that was to reinforce Orthodox Christian identity in a historically contested, multi-confessional area, labelling Jews as historical enemies. The third troparion in Ode VI begins with, "The Orthodox Christians who live around thy monastery endured much persecution at the hands of Jews and heretics..." This phrase would have meant little in central Russia, but had resonance in western Belarus and Ukraine: both were close to the border of the Catholic Habsburg Empire; the Pochaev Dormition Lavra had been under Greek Catholic control between 1720 and 1831. The text continues: “...yet, mindful of thy [Gavriil's] stand for the true Faith, they [the Orthodox Christians] in nowise fell away from the glorification of the true God and thine intercession." The text at the Litya enjoins Gavriil, who has "denounced Judaic foolishness through [his] bodily incorruptibility" (“безуміе іудейское нетлъніемъ твоего тълесе обличилъ еси,") to strengthen "us" against faithlessness and heresy (“насъ противу невърія и ереси молитвами твоими укрбпи”): “Ву your spilled blood, O Gabriel, the unrighteousness of the Jews is shamed and [their] heretical delusions exposed” (“Изліянною твоею кровію, Гавріиле...іудейское нечестіе посрамляется”). It dwells on the ghastliness of his being first tortured, then crucified "and pierced many times" ("ребра ему оружіемъ многажды прободоша"). “The Jews" wished to mock, negate, and invert Christ's passion, but are now themselves mocked and negated by Gavriil's passion, whereas Gavriil is enjoined to "affirm faith in Christ among the Russian people" (“въру Христову въ россійстъхъ людехъ утверди”). In this service, faith defines nationality; Orthodoxy defines Russianness.

Perhaps the strongest statement comes in the $9^{\text {th }}$ ode: "Now, too, as before be an intercessor for the Russian people before the Lord: then Christians underwent torture from Jews and heretics, now from both groups they are subjected to intense temptations..." (" $И$ нынъ...о народъ россіистьмъ буди пред Господомъ предстатель, якоже древле: тогда бо отъ іудей и еретикъ мученія Христіане пріимаху, нынъ же отъ обою соблазномъ вдаются лютъ...") [43, p. 17]. In both cases, early Christians and the contemporary Russian Christian narod are portrayed as passive ("innocent") victims of the crafty Jews and heretics. Gavriil is urged to help such passive Russians to overcome their lukewarm natures and perhaps by implication become more militant via repentance ("хладныя души покаяніемъ сокрушаяй”).

Other liturgical elements are used as well. Gavriil is compared to the Maccabee martyrs commemorated by the Jews on Hanukkah and the Orthodox at the beginning of the Dormition Fast on August 1 (but 'was made like unto them by the murderous action of their unworthy kin') [43]. This is one of numerous attempts to present contemporary Orthodox Christians as the 'true' heirs of righteous Jews, and contemporary Jews as breakers of their own tradition. The one place where Gavriil's killers are appealed to as pious Jews is in troparion 2, Ode VII, when the service asks: "Can ye fail to understand, o ye ungodly Jews, that ye make the God of your fathers your enemy when ye cruelly torture His innocent creature, thinking that by such ye would render Him service, O mindless ones?" [47, p. 105]. By evoking Herod and the slaughter of the innocents from the liturgical period after Christmas, the service prompts another image of an adult plotting the slaughter of small children-something that might have served handily in putting Mendel Beilis on trial for the murder of Andrei Iushchinskii. 
Finally, the service emphasizes the lower-class background of Martyr Gabriel's likely intended audience. His mother Anna is "humble-minded," his father Peter is "industrious." Consider the second troparion, Ode III: "The Lord is close to the poor and the afflicted, for, having permitted the ungodly to take a child from poor parents, he glorifieth the childless more than the kings of the earth, and kings and hierarchs bend their knees in prayer before their offspring." The implicit suggestion is that because Gabriel is now (1908) the object of a cult in imperial Russia, his parents are belatedly receiving the honor they never had in their lives. In short, the service to martyr Gabriel was an attempt to apply Orthodox liturgy to politics in borderland areas and appeal to a lower-class Orthodox Christian audience with long memories of being treated as third-class citizens. Although Metropolitan Antonii (Vadkovskii) tried to tone down some of the phrases, changing "O Jewish foolishness-the irrational dogs were wiser than you," to "O Jewish foolishnessthe irrational dogs who exposed you were witnesses;" and "Gavriil the infant takes on his passion from the Jews" to "Gavriil the infant takes on his passion for Christ," he did not succeed $^{5}$.

\section{Legacy and influence}

This service to Gavriil, and the cult of Gavriil in general, may have both reflected and helped to form Orthodox Christian attitudes to Jews in the Russian empire. Did they contribute to a climate making the Beilis case possible? The answer to this is not obvious. The service clearly made enough hierarchs nervous that they tried to minimize its reach and to limit it only to local veneration - the practice with other saints approved for local veneration in the last decades of the empire [22, p.312; 24, p. 355]. The Gavriil service was not included in the standard mineia collection of daily services, published in twelve volumes with one for each month, so its reach across the empire was limited-perhaps deliberately so ${ }^{6}$. Gavriil was not one of the saints in the Supplementary Mineia published in 1909, which included St. Feodosii of Chernigov, St. Serafim of Sarov, St. Job of Pochaev, and St. Tikhon of Voronezh [50]. It is not clear, in fact, if the service to Gavriil was ever conducted outside Minsk, Pochaev, and Slutsk.

It was a different matter in the Pale of Settlement. In May 1914, in the very same issue as it reported the local canonization of Gavriil, the Minsk Diocesan News printed an appeal for building a church on the grave of "the Christian martyr of our day" - Andrei Iushchinskii, the victim in the Beilis case [51]. One could hardly point to a more obvious attempt to channel Gavriil. Whether its reach was local or empire-wide, however, the renewed attention paid to 'martyr Gavriil' at the end of the nineteenth and the beginning of the twentieth centuries suggests that the cult both responded to and helped to foster a climate conducive to Orthodox Christians being prepared to admit the possibility of ritual murder of Christian children by their Jewish neighbors. The texts and images created in accusations of ritual murder-in this case, the cult of Martyr Gavriil and its liturgy - revealed social and religious tensions in a rapidly modernizing society and helped to establish and institutionalize the notion in years to come [52; 53, p. 243]. As Robert Weinberg

${ }^{5}$ Unpublished dissertation of Hieromonk German (Veinberg) shared by Aleksandr Kravetsky in a personal communication, June 30, 2019.

${ }^{6}$ By contrast, the service commissioned by Peter I on the occasion of the 1709 Russian victory at Poltava was prescribed to be served in every Orthodox church in the empire down through 1917. See [49]. 
noted, among non-Jews as well as Jews in the Russian Empire, the Beilis trial was "a struggle of two irreconcilable ways of perceiving and living in the world." There were those who thought that ritual murders could not exist "in the century of trams and airplanes" - and those who were convinced that the Jews were behind the evils of modernity. This is not to speak of those who continued to use amulets, incantations, chain letter prayers, incantations, and stolen hosts for magic purposes: in this mental universe, ritual murder did not appear to be a stretch. It was perfectly possible "for irrational fears to coexist with reason and rational thought." The service to Martyr Gavriil fostered those fears, and gave them Church sanction [53; 54, p. 240, 250].

There are some differences, however. While the Beilis case crystallized notions of Jewish identity in the Russian Empire, as the Tiszaeszlár case did in Hungary, there does not seem to be abundant evidence that the cult of Gavriil extended much beyond its environs in Pochaev and Slutsk. And in Russia there was no single visual counterpart of Gavriil to the portrait of the ostensible Hungarian victim, Eszter Solymosi ${ }^{7}$. But the region around Pochaev was more important than we might think. Faith Hillis and others have argued that Pochaev and Volyn', and right-bank Ukraine generally, were the core of a powerful Russian nationalist movement at the turn of the twentieth century. Claiming to restore the ancient customs of the East Slavs, the southwest's Russian nationalists sought to empower the ordinary Orthodox residents of the borderlands and to diminish the influence of their non-Orthodox minorities. As Hillis shows, by the first decade of the twentieth century, Pochaev's local nationalists secured a leading role in local mass politics. By 1910, with help from sympathetic officials in St. Petersburg, right-bank activists expanded their sights beyond the borderlands, hoping to spread their nationalizing agenda across the empire [55]. Anti-Semitism was among the means at their disposal. Thus it is not surprising that the cult of Gavriil took root precisely there: it was a potentially powerful tool for the modern nationalists' goals.

When Gavriil was locally canonized in Slutsk in 1914, the Minsk Diocesan News printed on its front pages both the telegram from Antonii, Archbishop of Volyn', reminding Nicholas II that only the Autocratic Rulers of the Russian land served as protectors of "long-suffering Belorussia," and Nicholas II's cordial response. An image of "holy martyr Gavriil of Slutsk" flanked by St. Lavrentii and the holy hierarch Kirill of Turov appeared on the first page of the paper's unofficial section (an earlier issue had urged every household to display such an icon of the local saints of Minsk) [56]. In his greeting to Archbishop Antonii of Volyn on the occasion of the canonization, Bishop Mitrofan of Minsk compared him to St. John Chrysostom for his eloquence in composing the service and emphasized the "from time immemorial Russian and Orthodox" nature of the Belorussian land. In his response, Antonii noted that "this sacred place [Gavriil's shrine] had been until recently all but forgotten," and that Gavriil's relics should "unite all believers of the southern and western lands like members of one family." Repeating themes from the service he wrote in 1908, he noted that the Russian intelligentsia had fallen away from understanding Orthodoxy, but that the pure, martyred Gavriil embodied the best characteristics of the Belorussian "tribe" (note that he did not use the word nation): "patience, humility, and meekness." In praising the thousands of local Orthodox Christians who gathered for the canonization, the article's writer noted how gratifying it was to see that their presence and

\footnotetext{
${ }^{7}$ For a discussion of the Russian exhibition and reception of the painting of Esther's murder in imperial Russia, see [52].
} 
enthusiasm showed that "the hearts of the Belorussians, pressured by Poles and Jews, still contain Russian Orthodox consciousness and religious feeling. It is necessary only to feed these feelings more often, and local holidays like this do just that" [40]. In greeting Antonii during the canonization, Priest A. Khvalebnov not only praised his authorship of the service, but also noted how successfully Antonii had rebutted the "thoughtless blasphemies concerning Gavriil permitted in Kiev" [41].

Not surprisingly given its connection to modern anti-Semitism, and to modern Orthodoxy in the service of modern nationalism, the cult of Gavriil would prove deadly for some of his devotees after the October revolution of 1917. Serving molebens to Gavriil in front of his Moscow reliquary, for example, helped to get prot. Ioann Vostorgov, the Dean of St. Basil's, arrested in 1918. The presiding judge at another trial, connected with the veneration of Gavriil, declared the use of his troparion and kondakion hymns to be "hateful and counter-revolutionary" [57]. Vostorgov became one of the first new martyrs and confessors of Russia. In 1919, numerous experts including Simon Dubnov joined the new Commission for Investigating Blood Libel Materials. The 'Ateist' publishing house printed a denunciation of ritual accusation explicitly linking Gavriil with the Beilis affair: it was called "The Holy Youth Gavriil: a medieval Beilisade" [58]. In the 1920s, the Soviet authorities killed the woman who initially brought the charge against Beilis, and vigorously prosecuted any accusations or discussions of Jews and ritual murder [59].

Perhaps because the Bolsheviks went after those who honored Gavriil, some of those who resisted the Bolsheviks chose to champion Gavriil even more. Gavriil, along with St. Afanasii, was one of two martyrs associated with the town of Brest to be included in the service to All Saints of Russia, revived and rewritten during the Council of 1917-1918 to reflect Bolshevik attacks on Orthodox Christianity [60]. Gavriil then continued to follow the vagaries of Soviet and post-Soviet rule. In the 1930s, the Slutsk monastery was closed; Gavriil's relics were transferred to the Museum of Atheism in Minsk. After the Nazi German invasion of Belarus, Gavriil's relics were returned to the Slutsk monastery. When the Germans retreated in 1944, they helped organize the transferal of Gavriil's relics from Minsk to Grodno to the church of the Protection of the Mother of God. A brief mention of Gavriil, along with all anti-Soviet references, was stricken from the revived but bowdlerized service to All Saints of Russia in the late 1940s. In a 1975 interview, Father Alexander Men' expressed the hope that Gavriil and several other saints might be 'decanonized,' as had happened in Roman Catholic practice during Vatican II in 1965 with such martyrs of blood accusation as Simon of Trent and Hugh of Lincoln [61].

However, this did not happen. In 1992, Gavriil's relics were transferred to the Polish Orthodox Church. They are now in the St. Nicholas Cathedral in Bialystok. Zwierki, the village that is Gavriil's birthplace, has a church dedicated to Martyr Gavriil. Despite several protests by the US Bureau of Democracy, Human Rights, and Labor, Gavriil is now an honored local saint among the Belarusian Orthodox in Poland, although slightly less so in Belarus itself. As at the start of the twentieth century, Gavriil seems to serve as a symbol of native Orthodox identity in a border region where Orthodoxy is a minority more than because of any specific details of his life [62]. Because of his age, he was dubbed the patron of the brotherhoods of Orthodox youth. Still, given that the population of Bialystok in 1936 was $50.9 \%$ Roman Catholic, $42.6 \%$ Jewish, and $8.2 \%$ Orthodox, while in 2019 it is $97 \%$ Polish and $2.5 \%$ Belarusian - and that the entire Jewish population of Zabludow was killed at Treblinka in November 1942 - the service's references empha- 
sizing Orthodox Christian victimhood at the hands of Jews are more than incongruous. This may be why the Polish Autocephalous Orthodox Church, the Belarusian Exarchate of the Moscow Patriarchate, and churches based in the United States removed the references to Jewish "murderers" from the vita, replacing them with 'adepts of a satanic sect,' and emphasizing only God's Providence in preserving the boy's body incorrupt and the healings of children at his relics [63-67]. The sole reference to Gavriil in the text of the service to all the saints of Belarus' is an easy-to-miss troparion in Ode VII of the canon: "Enduring as an infant great torments from Jews repugnant to God, thou has become like a Heavenly Angel, o passion-bearer Gabriel; pray now for the all the children of our land" [68]. These attempts at softening tensions, however, pale next to the fact that the minea editions published in 1978-1989 and 2002 - that is, publications meant for the use of the entire Russian Orthodox Church - both contain the service with all the references to Jews as killers still present [48]. This may be the reason why it was included among the services of the Russian Orthodox Church of Russia in the English translation of its minea [47]. This enshrined liturgical commemoration is more serious than the service's reach on independent websites.

It should be noted, however, that in both cases, Martyr Gavriil appears third in rank for April 20. It would therefore be simple for a parish priest to opt for another, more highly-ranked saint for that day (St. Fedor Trikhina or St. Aleksandr Oshenevskii, both monks - prepodobnye). Other official websites preserve the original wording of both the troparion and kontakion and the Life, including such phrases as "You, o holy infant Gabriel, for the sake of the One Stabbed by the Jews for our sake was viciously stabbed by them," and "O Martyr of Christ Gabriel, you were seized by true beasts - Jews" [69]. It is thus hard to claim that veneration of Gavriil is innocent. Although Patriarch Kirill was careful to emphasize Gavriil's local cult on his visit to Poland in August 2012, his veneration of the relics as such prompted criticism in the progressive Russian-language press [70 $]^{8}$.

When ritual murder charges resurface in Orthodox Christianity, the spectre of Gavriil is again evoked. The 1979 murder of a Greek Orthodox monk in Israel by a mentally unstable observant Jew, and the monk's subsequent canonization in 2009, prompted both accusations of ritual murder in popular literature and liturgy, though not in the official statements of the Jerusalem Patriarchate. In recounting the vita and martyrdom of (St.) Monk Philoumenos, unofficial Belarusian Orthodox publications explicitly connected him to Gavriil of Bialystok; in adding Philoumenos to its own lists of saints in 2010, the Moscow Patriarchate mentioned only that "fanatics of other faiths" committed the murder $[72 ; 73]^{9}$. Early twenty-first century inhabitants of former shtetls with lively associations and recollections of blood accusation did not once mention Gavriil, though the tropes of Christ and the Eucharist persisted [75].

We can thus propose the following conclusions.

The cult of Gavriil of Bialystok arose initially in the context of Uniate/Orthodox/ Jewish tensions in the Polish-Lithuanian Commonwealth, and remained a strictly local phenomenon in present-day Belarus and western Ukraine until the end of the nineteenth century.

8 "But see the reportage of the same subject by the official organ of the Moscow Patriarchate: [71].

${ }^{9}$ For an account of the ritual murder theme in the martyr accounts of St. Philoumenos, including a brief discussion of Gavriil, see [74]. 
The modernization in the Russian Empire sparked by the Great Reforms of Alexander II, and the emphasis on Russian nationalism by Alexander III and Nicholas II, led to heightened confessional and ethnic tensions and to a flowering of the cult of Gavriil in a borderland area crucial in the articulation of modern, anti-Semitic nationalism.

The 1917 revolution - that is, the apparent triumph of secular modernity - led to a condemnation of blood accusation, and to an explicit, negative linkage of St. Gavriil with the Beilis case.

Despite numerous protests, and despite the fading of the resonance of blood accusation, the cult of St. Gavriil of Bialystok is still with us - among Belarusian Orthodox Christians, especially in Poland, primarily on national grounds, and elsewhere primarily because of anti-Semitism or inertia. Thus, although blood accusation was strongest when linked to other processes connected to modernity and mass politics, when linked to religious veneration, modern folklore, and nationalism, blood accusation can and does persist to our day.

\section{References}

1. Glazenap, I. O. (ed.) (2006), The Killing of Andrei of Kiev: The Beilis Case. Verbatim Report of the Kiev Trial., Russkaia ideia Publ., Moscow. (In Russian)

2. Head, T. (ed.) (2000), Medieval Hagiography, Routledge, New York and London.

3. Scholasticus, S. (1886), "The Jews Commit Another Outrage upon the Christians and are Punished,' The Ecclesiastical History of Socrates Scholasticus", in Zenos, A.C. (ed.), Nicene and Post-Nicene Fathers, Ser. II, vol. II, W.M.Eerdmans, Grand Rapids, MI, available at: http://www.sacred-texts.com/chr/ ecf/202/2020233.html (accessed: 22.02.2020).

4. Stow, K. (1998), Alienated Minority: The Jews of Medieval Latin Europe, Harvard University Press, Cambridge, MA.

5. Toaff, A. (2007), Pasque di sangue: ebrei d'Europa e omicidi rituali, Il Mulino, Bologna.

6. Avrutin, E., Dekel-Chen, J., and Weinberg, R. (eds) (2017), Ritual Murder in Russia, Eastern Europe, and Beyond: New Histories of an Old Accusation, Indiana University Press, Bloomington.

7. Engelstein, L. (1990), The Keys to Happiness: Sex and the Search for Modernity in Fin-de-Siècle Russia, Cornell University Press, Ithaca.

8. Langmuir G. (1990), Toward a Definition of Anti-Semitism, University of California Press, Berkeley.

9. Johnson, Hannah R. (2012), Blood Libel: The Ritual Murder Accusation at the Limit of Jewish History, University of Michigan Press, Ann Arbor. York.

10. Avrutin, E. (2017), The Velizh Affair: Blood Libel in a Russian Town, Oxford University Press, New

11. Naienko, G.M. (2014), The Polemical Text “The True Messiah" by Ioannikyi Galiatovskyi as a scholarly-popular text of the XVII century, Vestnik of Pushkin Leningrad State University, pp.86-94. (In Russian)

12. Haliatovskyi, I. (1669), The True Messiah, Kievo-Pecherskaia Lavra Publ., Kiev, pp.385-389. (In Ukrainian)

13. Ionita, A. and Tobler, S. (2020), The Orthodox Liturgy and Anti-Judaism, Peter Lang, Bern.

14. The Second Vatican Council (1965), Declaration on the Relationship of the Church to Non-Christian Religions (Nostra Aetate), October 28, available at: http://www.vatican.va/archive/hist_councils/ii_vatican_ council/documents/vat-ii_decl_19651028_nostra-aetate_en.html (accessed: 22.02.2020).

15. Notes on the Correct Way to Present the Jews and Judaism in Preaching and Catechesis of the Roman Catholic Church, June 24, 1985, available at: http://www.usccb.org/prayer-and-worship/liturgical-year/lent/ guidelines-for-catholic-jewish-relations.cfm (accessed: 22.02.2020).

16. Ivanov, A. (2011), “The Saint of the 'Russian Reformation': St. Tikhon of Zadonsk and the Impact of Protestantism in Eighteenth Century Orthodox Church", in Potter, C., Spock, J. and Chrissidis, N. (eds), Religion and National Identity in Russia and the Soviet Union, Indiana University Press, Bloomington, pp. 81-106.

17. Skinner, B. (2009), The Western Front of the Eastern Church: Uniate and Orthodox Conflict in Eighteenth-Century Poland, Ukraine, Belarus, and Russia, Northern Illinois University Press, DeKalb, IL. 
18. Amvrosii, Arkhim. (1815), History of the Russian Hierarchy, Synodal Publ., Moscow. (In Russian)

19. Eristov, D. A. (1862), Historical Dictionary of Saints Glorified in the Russian Church and of Some Devotees of Piety Locally Honored, $2^{\text {nd }}$ ed. Tipografiia II Otdeleniia sobstvennoi E. I. V. Kantseliarii Publ., St. Petersburg. (In Russian)

20. Filaret (Gumilevskii), Archbishop of Chernigov (1865), Russian Saints Venerated by the Entire Church or Locally: An Attempt at Describing Their Lives, $2^{\text {nd }}$ ed. Tipografiia Iliinskogo monastyria Publ., Chernigov. (In Russian)

21. Freeze, G. (1996), Subversive piety: religion and the political crisis in late imperial Russia, The Journal of Modern History, vol. 68, no. 2, pp. 308-350.

22. Zhizneopisaniia otechestvennykh podvizhnikov blagochestiia 18 i 19 vekov, March (1907), Izdanie Afonskago Russkago Panteleimonova monastyria Publ., Moscow. (In Russian)

23. Tkachev, E. V. (2012), "Canonization", in Pravoslavnaia entsiklopediia, vol. XXX, Moscow, pp. 269359. (In Russian)

24. Andronik (Trubachev) (2000), The Canonization of Saints in the Russian Orthodox Church Between 1721 and 1894, available at: https://azbyka.ru/kanonizaciya-svyatyx-v-russkoj-pravoslavnoj-cerkvi4_kanonizatsija_svjatykh_v_1721_1894_gg (accessed: 22.02.2020). (In Russian)

25. Parppei K. (2011), "The Oldest One in Russia": The Formation of the Historiographical Image of Valaam Monastery, Brill Publ., Leiden.

26. Wortman R. (2000), Scenarios of Power: Myth and Ceremony in Russian Monarchy, vol. 2, Princeton University Press, Princeton.

27. Lavrov A.S. (2000), Witchcraft and religion in Russia, 1700-1740, Drevlekhranilishche Publ., Moscow. (In Russian)

28. Kharkevich, Ia. and Cherepitsa, V.N. (2005), "Gavriil”, in Pravoslavnaia Entsiklopediia, vol.X, Tserkovno-nauchnyi tsentr "Pravoslavnaia Entsiklopediia" Publ., Moscow. (In Russian)

29. Panchenko, A. A. (2002), Blood libel, The Khlystovshchina and the Self-Castrators: the Folklore and the Traditional Culture of Russian Mystical Sects, OGI Publ., Moscow. (In Russian)

30. Khvol'son, D. A. (1880), On Some Medieval Accusations Against Jews: a History According to the Sources, $2^{\text {nd }}$ ed., Tipografiia Tsederbauma i Gol'denbluma Publ., St. Petersburg. (In Russian)

31. Weinberg R. (2013), Blood Libel in Late Imperial Russia: The Ritual Murder Trial of Mendel Beilis, Indiana University Press Publ., Bloomington.

32. Liutostanskii, Ippolit (hieromonk) (1876), The question of the use of Christian blood by Jewish sectarians for religious purposes in connection with the question of the relation of Jewry to Christianity in general, Frum Publ., Moscow. (In Russian)

33. [Dal' V.?] [Skripitsyn?] (1844), The search for Jews killing Christian babies, St. Petersburg, repr., available at: http://web.petrsu.ru/ dahl/html/pdf/ROZYSK.pdf (accessed: 22.02.2020). (In Russian)

34. Reznik, S. (2010), 'Spotted Dal': Who is the author of the book "A Search for Ritual Killings"?, Novoe literaturnoe obozrenie Publ., Moscow, 104 p. (In Russian)

35. Gessen, Iu. I. (1914), Note on the ritual killings (attributed to V. I. Dahl), L. A. Glazenburg Publ., St. Petersburg. (In Russian)

36. Weinberg R. (1993), The Revolution of 1905 in Odessa: Blood on the Steps, Indiana University Press, Bloomington.

37. Vulpius, R. (2005), Nationalisierung der Religion: Russifizierungspolitik und ukrainische Nationsbildung 1860-1920, Harrassowitz Verlag, Wiesbaden.

38. Osadczy W. (2007), Holy Russia. Development and impact of the idea of Orthodoxy in Galicia, Wydawnictwo Uniwersytetu Marii Curie-Skłodowskiej Publ., Lublin, pp. 358-362.

39. Antonii (Bishop) and Sergiev, I. (1903), The Homily of Bishop Anthony (Khrapovitskii) and Ioann of Kronstadt concerning the violence of Christians against Jews in Chisinau, Odessa. (In Russian)

40. Mitrofan (Bishop), For the Slutsk celebrations: the visit of Archbishop Antonii of Volyn' to Minsk, Minskiia eparkhial'nyia viedomosti, no. 9 (1 May), pp.202-205, available at: http://pravoslavnoe-duhovenstvo.ru/media/priestdb/materialattachment/attachment/bf/64/bf64006a-5cd0-4c00-ad29-31cf41bccdfc.pdf (accessed: 22.02.2020). (In Russian)

41. Khvalebnov, A. (Priest) (1914), Welcoming speech, Minskiia eparkhial'nyia vedomosti, no. 9 (1 May), pp.209-210, available at: http://pravoslavnoe-duhovenstvo.ru/media/priestdb/materialattachment/attachment/bf/64/bf64006a-5cd0-4c00-ad29-31cf41bccdfc.pdf (accessed: 22.02.2020). (In Russian)

42. Cases of healing during the transfer of a fragment of the holy relics of the holy infant martyr Gabriel of Zabludowa (1909), Grodnenskie eparkhial'nye vedomosti, no. 16 (19 April), p. 69. (In Russian) 
43. Service to the Holy Martyr Gabriel the Infant, martyred in the year of our Lord year 1690 in Bielostok (1908), Tipografia Pochaevo-Uspenskiia Lavry Publ., Pochaev. (In Church Slavonic)

44. Dymshits, V. (ed.) (2010), Jewish folk tales compiled by E. S. Raise, Symposium Publ., Moscow. (In Russian)

45. Dandes A. (2003), "'Blood libel' or the legend of ritual murder: anti-Semitism through the prism of projective inversion", in Fol'klor: semiotika i/ili psikhoanaliz: sbornik statei, Vostochnaia literatura Publ., Moscow. (In Russian)

46. Postnaia Triod' (1907), Tipografiia Kievo-Pecherskoi Uspenskoi Lavry Publ., Kiev. (In Church Slavonic)

47. [Antonii (Khrapovitskii), Bishop] (2008), "Also on the $20^{\text {th }}$ Day of the Month of April: Commemoration of the Child-Martyr Gabriel of Bialystok", in The Menaion of the Orthodox Church: April (VIII), $2^{\text {nd }}$ ed., St. John of Kronstadt Press, Liberty, TN.

48. Holy Martyr Gabriel, infant of Bialystok (1978-1989), Zelenye minei, Moscow, pp. 87-98, available at: https://azbyka.ru/days/assets/upload/minei/04/minea_04_20.pdf (accessed: 22.02.2020). (In Russianfont Church Slavonic)

49. Kizenko, N. (2012), "The Poltava Battle in Language and Liturgy", in Poltava 1709: The Battle and the Myth. Ed. Serhii Plokhy, Harvard Papers in Ukrainian Studies, Ukrainian Research Institute of Harvard University, Distributed by Harvard University Press, Cambridge, Mass., pp. 227-244.

50. Dopolnitel'naia mineia (1909), St. Peterburgskaia Sinodal'naia Tipografiia Publ., St. Petersburg. (In Russian-font Church Slavonic)

51. Appeal (1914), Minskiia Eparkhial'nyia Viedomosti, no. 9 (1 May), pp. 216-218, available at: http:// pravoslavnoe-duhovenstvo.ru/media/priestdb/materialattachment/attachment/bf/64/bf64006a-5cd0-4c00ad29-31cf41bccdfc.pdf (accessed: 22.02.2020). (In Russian)

52. Véri, D. (2016), The Tiszaeszlár Blood Libel: Image and Propaganda, Nineteenth-Century AntiSemitism in International Perspective, Open Peer Review, 13.12, available at: https://mws.hypotheses. org/37349, https://antisem19c.hypotheses.org/742 (accessed: 26.12.2019).

53. Murav, H. (2000), The Beilis Ritual Murder Trial and Culture of Apocalypse, Cardozo Studies in Law and Literature, vol. 12, no. 2, pp. 243-263.

54. Weinberg R. (2015), "Connecting the Dots: Jewish Mysticism, Ritual Murder, and the Trial of Mendel Beilis", di Salvo, M. et al. (eds), in Word and Image in Russian History: Essays in Honor of Gary Marker, Academic Studies Press, Boston, pp. 238-252.

55. Hillis, F. (2013), Children of Rus': Right-Bank Ukraine and the Invention of a Russian Nation, Cornell University Press Publ., Ithaca, NY.

56. District message to the Minsk flock (1914), Minskiia Eparkhial'nyia Viedomosti, 1 February, vol.3, pp. 43-46. (In Russian)

57. The Holy Lad Gabriel (A Case of Anti-Semitic Agitation in St. Basil's Cathedral: Echoes of the Beilis Case) (1919), Revoliutsiia i tserkov', no. 6-8, pp. 62-76. (In Russian)

58. The holy youth Gavriel: a medieval Beilisiade: a case of anti-Semitic agitation in the Moscow Cathedral of St. Basil the Blessed in connection with the discovery in it of the bier of the martyr Gabriel (1920), Ateist Publ., Moscow, available at: http://www.1archive-online.com/archive/rushkovsky/beylis.html (accessed: 26.12.2019). (In Russian)

59. Bemporad, E. (2019), Legacy of Blood: Jews, Pogroms, and Ritual Murder in the Lands of the Soviets, Oxford University Press, New York.

60. Orthodox church calendar, available at: http://azbyka.ru/days/vseh_svetih_v_zemle_ruskoi-all. shtml (accessed: 22.02.2020). (In Russian)

61. An Imaginary Martyr and a Real One: Infant Gabriel and Aleksandr' Men', available at: http://yakov.works/library/17_r/radio_svoboda/20120908.htm (accessed: 22.02.2020). (In Russian)

62. Krikhtova, T. (2009), The image of Gabriel Bialystok in the perception of Christians and Jews of modern Belarus, available at: http://www.jcrelations.net/.2982.0.html?L=7 (accessed: 27.12.2019). (In Russian)

63. Patriarch Kirill Met Thousands in Bielostok, available at: http://church.by/news/v-belostoke-patriarha-kirilla-vstrechali-tysjachi-ljudej (accessed: 22.02.2020). (In Russian)

64. Archbishop Iakov of Bielostok Brings a Portion of the Relics of Gavriil the Martyr to Ekaterinburg, available at: http://church.by/news/arhiepiskop-belostokskij-iakov-dostavit-v-ekaterinburg-chasticumoshej-muchenika-mladenca-gavriila (accessed: 22.02.2020). (In Russian)

65. Artemii, Archbishop of Grodno, Blesses a Chapel in Honor of Infant Martyr Gavriil of Bielostok in the Village of Rybnica, available at: http://church.by/news/arhiepiskop-grodnenskij-i-volkovysskij-artemij-sov- 
ershil-chin-osvjashenija-chasovni-v-chest-muchenika-mladenca-gavriila-belostoskogo-v-derevne-rybnica (accessed: 22.02.2020). (In Russian)

66. Holy Martyr Gavriil of Bielostok, available at: http://www.brooklyn-church.org/svyatoj-muchenikmladenec-gavriil-belostokskij.html brooklyn (accessed: 22.02.2020). (In Russian)

67. Infant Martyr Gavriil of Bielostok, available at: http://sluck-eparchiya.by/svjatye-i-svjatyni/svjatye/ muchenik-mladenec-gavriil-belostokskij (accessed: 22.02.2020). (In Russian)

68. The service of all the saints of the land of Belarus, available at: http://sppsobor.by/bractva/vilna/slbel-sv/11989 (accessed: 22.02.2020). (In Russian)

69. Martyr Gavriil of Bielostok, Infant of Slutsk, available at: https://azbyka.ru/days/sv-gavriilbelostokskij-slutskij-mladenets (accessed: 22.02.2020). (In Russian)

70. A Libelous Shrine, available at: http://grani.ru/opinion/m.199981.html (accessed: 22.02.2020). (In Russian)

71. Patriarch Kirill Venerates the Shrines of Bielostok, available at: http://www.patriarchia.ru/db/ text/2413961.html/ (accessed: 22.02.2020). (In Russian)

72. The Memory of Philoumenos of the Holy Sepulchre, Tortured to Death by the Judeans in 1979, available at: https://www.odigitria.by/2011/11/29/pamyat-filumena-svyatogrobca-v-1979-godu-iudeyamiumuchennogo/ (accessed: 22.02.2020). (In Russian)

73. Minutes of the Meeting of the Holy Synod from 5 March 2010, available at: http://www.patriarchia. $\mathrm{ru} / \mathrm{db} / \mathrm{text} / 1106470 . \mathrm{html}$ (accessed: 22.02.2020). (In Russian)

74. Gurevich, D. and Harani, Y. (2018), "From Christian Antisemitism to New Antisemitism: The Case of Philoumenos of Jacob's Well", in Small, C. A. (ed.), Antisemitism in Comparative Perspective, vol.3, ISGAP Publ., New York, pp. 139-170.

75. L'vov, A.L. (2006), "Blood and matzoh: texts, practices, meanings", in Religioznye praktiki v sovremennoj Rossii: Sbornik statei, Rousselet, C. and Agadjanian, A. (eds), Novoe izdatel'stvo Publ., Moscow, pp. 51-68. (In Russian)

Received: January 3, 2019

Accepted: December 11, 2019

Author's information:

Nadieszda Kizenko — PhD, Professor; nkizenko@albany.edu

\section{Кровавый навет и литургия в православии в Российской империи: до и после дела Бейлиса}

\section{Н. Киценко}

Государственный университет штата Нью-Йорк, Олбани, США, 12222, Олбани, Нью-Йорк, Вашингтон авеню, 1400

Для цитирования: Kitsenko N. Blood accusation and Orthodox liturgy in the Russian Empire before and after the Beilis Case // Вестник Санкт-Петербургского университета. Философия и конфликтология. 2020. Т. 36. Вып. 1. С. 179-195. https://doi.org/10.21638/spbu17.2020.115

«Мученик» Гавриил Белостокский скончался в 1690 году, но стал объектом почитания только в конце XIX в. Этот период, ставший золотым веком для «изобретения традиций» (Эрик Хобсбаум), в Российской империи был отмечен также ростом антисемитизма и обвинений в ритуальных убийствах. Служба, составленная в честь Гавриила в 1908 г. - малая вечерня, великая вечерня, утреня, - содержит множество цитат и переработанных отрывков антисемитского характера из служб Страстной Недели, в частности Великой пятницы. В византийской литургии мы находим знакомые и очень характерные мотивы, позволяющие провести параллель с ситуацией, которая сложилась в Российской империи между революциями 1905 и 1917 гг. Служба Гаври- 
илу заставляет задуматься о том, в какой степени литургические тексты повлияли на возникновение христианского религиозного антисемитизма. Кроме того, она позволяет понять, почему в позднеимперской России с евреями было связано столько тревог и как стало возможным дело Бейлиса (1911-1913), в основе которого лежал кровавый навет. Большинство историков утверждают, что к началу XX в. религиозные основы антисемитизма сменились отрицательной реакцией на появление либеральной и марксистской идеологий, а в Российской империи - также на ускорившуюся интеграцию евреев в русское общество вследствие Великих реформ Александра II. Однако служба Гавриилу и непрекращающиеся инциденты во время Страстной недели показывают, что религиозная составляющая ритуальных убийств и обвинений сохраняла свое значение. Почитание Гавриила в Польше, Белоруссии и Литве в советский и постсоветский период свидетельствует о существовании различных источников напряженности.

Ключевые слова: кровавый навет, ритуальное убийство, Гавриил Белостокский, дело Бейлиса, Слуцк, Иоанникий (Галятовский), Антоний (Храповицкий).

Статья поступила в редакцию 3 января 2019 г.; рекомендована в печать 11 декабря 2019 г.

Контактная информация:

Киценко Надежда — канд. филос. наук, проф.; nkizenko@albany.edu 